Société d'histoire de la révolution de 1848 et des

révolutions du XIXe siècle

\title{
Une œuvre de préservation sociale : le Bon- Pasteur de Varennes-les-Nevers (1852-1883)
}

\section{Simone Waquet}

\section{OpenEdition Journals}

Electronic version

URL: http://journals.openedition.org/rh19/62

DOI: $10.4000 /$ rh 19.62

ISSN: $1777-5329$

\section{Publisher}

La Société de 1848

\section{Printed version}

Date of publication: 1 June 1992

ISSN: 1265-1354

\section{Electronic reference}

Simone Waquet, «Une œuvre de préservation sociale : le Bon-Pasteur de Varennes-les-Nevers (1852-1883) », Revue d'histoire du XIXe siècle [Online], 8 | 1992, Online since 04 September 2008, connection on 01 May 2019. URL : http://journals.openedition.org/rh19/62 ; DOI : 10.4000/rh19.62

This text was automatically generated on 1 May 2019.

Tous droits réservés 


\section{Une œuvre de préservation sociale : le Bon-Pasteur de Varennes-les-Nevers (1852-1883)}

Simone Waquet

\section{ABSTRACTS}

No abstract available by now

Pas de résumé disponible actuellement

INDEX

Mots-clés: Jeunesse, Histoire sociale 